Article

\title{
Gender Matters: Climate Change, Gender Bias, and Women's Farming in the Global South and North
}

\author{
Tricia Glazebrook ${ }^{1, *} \mathbb{D}$, Samantha Noll $^{1}$ and Emmanuela Opoku ${ }^{2}$ \\ 1 School of Politics, Philosophy and Public Affairs, Washington State University, Pullman, WA 99164, USA; \\ sam.noll@wsu.edu \\ 2 Department of Environmental Science, University for Development Studies, Navrongo, Ghana; \\ EmmanuelaOpoku@my.unt.edu \\ * Correspondence: patricia.glazebrook@wsu.edu; Tel.: +1-509-335-2544
}

Received: 1 June 2020; Accepted: 29 June 2020; Published: 3 July 2020

\begin{abstract}
Can investing in women's agriculture increase productivity? This paper argues that it can. We assess climate and gender bias impacts on women's production in the global South and North and challenge the male model of agricultural development to argue further that women's farming approaches can be more sustainable. Level-based analysis (global, regional, local) draws on a literature review, including the authors' published longitudinal field research in Ghana and the United States. Women farmers are shown to be undervalued and to work harder, with fewer resources, for less compensation; gender bias challenges are shared globally while economic disparities differentiate; breaches of distributive, gender, and intergenerational justices as well as compromise of food sovereignty affect women everywhere. We conclude that investing in women's agriculture needs more than standard approaches of capital and technology investment. Effective 'investment' would include systemic interventions into agricultural policy, governance, education, and industry; be directed at men as well as women; and use gender metrics, for example, quotas, budgets, vulnerability and impacts assessments, to generate assessment reports and track gender parity in agriculture. Increasing women's access, capacity, and productivity cannot succeed without men's awareness and proactivity. Systemic change can increase productivity and sustainability.
\end{abstract}

Keywords: Africa/Ghana; climate change; farming/farmers; food security; gender inequality; global South/North; hunger; justice; land

\section{Introduction}

According to the United Nations (UN) Food and Agriculture Organization (FAO), almost half (45\%) of the global population, i.e., 3.1 billion people, live in rural areas. Approximately 2.5 billion of these rural dwellers depend on agriculture for their livelihood and means of subsistence [1]. A quarter of the world's population are women living in rural areas. It therefore can be concluded that 1.73 billion women live in rural areas, and that for 1.4 billion of these women, agriculture is their primary livelihood. Just over a third of these women, i.e., 500 million, are 'peasants' who do not own land and receive barely $5 \%$ of available agricultural resources [1]. Women make up $43 \%$ of the workforce in the global South, and half of this $43 \%$ live in sub-Saharan Africa [1]. This means that women in sub-Saharan Africa are $21.5 \%$, i.e., well over a fifth, of the workforce in the global South. In agriculture, in the global South as a whole, women constitute $43 \%$ of the workforce and approximately $66 \%$ of livestock keepers [2]. That is, women contribute substantially to national food-baskets in the global South and their agricultural productivity is crucial for meeting food security. The productivity of at least 500 million women is, however, hampered by limited access to land and resources. 
Women's labor contribution alone suggests that their situations as agriculturalists are likely, even substantially, different in the global South and North. The global North, according to recent census data, is seeing a resurgence of female farmers. In Europe, the number of women farmers has been rising steadily for over thirty years [3]. By 2016, approximately $30 \%$ of farms were managed by women across the European Union (EU), though this statistic hides significant variations between countries in that Eastern European countries tend to have significantly higher numbers of female producers [4]. Likewise, Canada is experiencing a steady rise in the number of female farmers who now make up approximately $28 \%$ of Canadian farmers [5]. Australian politicians decided in the 1890 s not to record women's farm work in public records such as censuses, so women's contributions have gone unrecorded until recently [6]. Nonetheless, Australia reached gender parity in agricultural education by 2003 , and by $2017,32 \%$ of the agricultural workforce was female [7]. In the United States (U.S.), the average farmer used to be a white male in his sixties [8], though a family-operated farm is not necessarily owned by that family: the 'operator' may live in a different state but be listed to receive farm payments. Data was not collected on women farmers until 1978 [8]. Survey data was collected based on land ownership and thus, by design, excludes those who perform work but are not property owners, as has been the case for many women.

The 2017 U.S. Department of Agriculture (USDA) census found that the proportion of male farmers had fallen, while female producers rose from $27 \%$ to $36 \%$ [9]. It is not clear, however, whether women's participation in farming had increased, or if women had simply been made more visible. The USDA had changed its data collection method to allow more than one 'primary producer,' which meant that women who had previously been overlooked would now be accounted for. Nor do rising numbers necessarily indicate progress in gender parity concerning income and control of resources. In the U.S., newer farms tend to be smaller, with fewer acres but more diverse crop selection, and lower sales $[9,10]$. If more women are entering the agricultural sector, this trend may indicate that distribution of property, resources, and economic opportunities is not gender equitable. While women farmers in the U.S. are moving towards gender parity, improvement in landownership practices are needed for women to be competitively productive. Even with these caveats, however, the substantial contribution that women farmers have made and continue to make in the global North cannot be ignored.

Women in the global South make a substantially larger contribution to food security, and they too would benefit greatly from more and better access to land. Little research exists, however, examining broad-scale differentiation between women farmers' situations and challenges across the South-North division: a knowledge gap exists concerning what the similarities and differences are, and more importantly, how they affect women's agricultural productivity, sustainability, and efficiency. This knowledge is significant because, of the world's 795 million people going hungry in 2015, 780 million-over 98\%-were in the global South [11] (pp. 8-9), with 220 million-27\%-in sub-Saharan Africa in particular [11] (p. 10). In 2018, 257 million people, i.e., 20\% of Africa's population, went hungry-more than in any other region [12]. That the global hunger burden should fall so disproportionately to regions that have suffered colonial exploitation of resources and labor and continue to experience post-colonial harms, and to women, is a breach of distributive justice at an unprecedented scale. Moreover, climate impacts are threatening and damaging productivity increasingly in Africa.

Much agro-research is conducted in the global North, so a better understanding of African women's unique challenges as farmers in the global South rather than as women who farm, may open pathways toward better-fitting solutions. At the same time, more understanding of the challenges that women face globally as farmers may open new pathways for knowledge transfer across the South-North divide. There are many issues to consider and we cannot address them all here but aim at broad identification of issues in a preliminary comparative analysis of impacts of climate change, gender bias, and land access on women's agricultural productivity in the global South and North, with particular attention to women in the South who farm at the intersection of gender, food production, and poverty. 
In aiming at this goal, we show that despite very different circumstances, women farmers in the global South and North are subject to similar biases and inequalities that hamper their productivity. It stands to reason, then, that removing these impediments would increase their output. We discuss below the argument that there is inadequate evidence to conclude that this is the case because a lack of evidence may be used to buttress existing gender biases that make farming more challenging for women than men. Our intent is not to conclude that women would necessarily choose to participate fully in large-scale, industrial farming. Of course, women might, in which case we are confident that, if equally resourced, they could readily compete with men. Rather, our research shows that women's farming tends toward models not readily compatible with industrial farming that, for example, uses pesticides and antibiotics. That is, we challenge the male model of agricultural development that has been shown to be fragile in the face of climate change. This is not to idealize women or their farming practices. Women's subsistence agriculture in the global South, where crises in food security are already well under way, is extremely vulnerable to climate change. Rather, our intent is to open possibilities for further thinking about women's farming in terms of better meeting their needs, whether their goal is securing family food security or a livelihood.

With respect to our terminology, by 'livelihood' we mean more than income generation and include also broader factors, for example, equity, justice, and rights that support quality of life. By 'investing in women's farming,' we mean providing access to resources and finance. Our conclusions in Section 9 provide a deeper account of what such investment means, beyond resources such as technologies and finance. We likewise use 'productivity' not in the sense of increased output that prioritizes profits but in terms of output increases—or at least reduced decreases, as is more commonly the case for women subsistence farmers in the global South impacted by climate change-that prioritize sustainable livelihoods, whether subsistence in the South or income-generating in the North. Injustices in food security and sovereignty, lived experiences of gender, and intergenerational and women's rights are also identified (see Appendix A). As a corollary, connection between women's increased participation in agriculture and their long-term potential to shift contemporary farming values and goals toward more sustainable practices is assessed.

\section{Methods}

We draw conclusions from the data rather than constraining analysis with a priori theory, though we do draw on theoretical concepts such as 'the feminization of poverty,' 'the feminization of agriculture,' and the 'invisibility of women's labor.' We work at three levels:

- The global level, including South/North distinctions;

- The regional level by drilling down to sub-Saharan Africa (subsequently 'Africa'), with some reference to Latin America and Asia, in the global South, and focus primarily on North America in the global North with reference also to Europe; and,

- The local level, using Ghana as an example in Africa and primarily the U.S. with discussion of Canada, European countries, and Australia in the global North.

Our intent in level-based analytic structure is to balance on-the-ground women's concrete, lived experience drawn from our field research with broader studies of global and regional trends in order to avoid both empty generalization and parochial uniqueness.

In the global South, Africa is chosen because humanitarian crises in hunger are underway throughout the region in multiple, intersecting breaches of distributive justice with respect to gender, including loss of food sovereignty, agriculture and food security, and future generations. Ghana is chosen because it shares an ecosystem, the Sudan Savannah, with multiple countries stretching from the Atlantic well into East Africa and some common cultural contexts concerning gender. Glazebrook and Opoku have amassed longitudinal data on women's farming in north-east Ghana since 2007 using interviews, focus groups, participant observation, photovoice, and participatory rural appraisals, including schedule drawing of daily and seasonal work and informal mapping during transect 
walks $[13,14]$. In the global North, our research focuses on the U.S., including Noll's field work using interviews and focus groups [15], but is broader in its regional discussion of Europe and Australia, with analysis also at the country level, including Canada and European countries based on available research.

Our approach has been to collect and categorize research so that issues could emerge from the research itself and provide solid ground for identifying commonalities and differences between the global South and North rather than overdetermination by one. We found that North and South have multiple issues in common, but also glaring differences. Research is presented in sections that discuss both South and North with immediate comment on commonalities, differences, justice issues, and productivity impacts. Sections overview women's farming and situations before addressing climate impacts on productivity and food security, biases and barriers that constrain women's farming, and land acquisition and retention. Broader conclusions across these themes are then discussed, followed by recommendations for addressing the challenges that hamper women's agricultural productivity.

It must be acknowledged that the focus is on gender injustice, but indigenous communities, including women, are often traditional agriculturalists and represent $5 \%$ of the planet's human population while carrying $15 \%$ of the world's extreme poverty burden and constituting a third of the rural poor [16]. In the global North, traditional food practices have been shattered by, for example, confinement to reservations that precludes long hunts [17] and polluting and damming of rivers that decimate salmon stocks [18]. In the South, indigenous groups fight to protect their land, water, and crops from appropriation and damage by resource extraction industries, and increasing numbers are murdered in consequence [14]. This paper is dedicated to Berta Carceres and all who have lost their life protecting land, ecosystems, water, and traditional farming.

\section{Women Farmers}

On average, $83 \%$ of the $697 \mathrm{kgs}$ of food, containing $93 \%$ of the calories and $80 \%$ of the protein, that is consumed per person per year, comes from terrestrial production [19]. In Oceania, Southern Asia, and sub-Saharan Africa, agriculture employs about $60 \%$ of women, though in the Least Developed Countries in these regions, $80 \%$ of women work in agriculture with as many as $90 \%$ in some African countries [20]. Women in rural areas grow most of the crops for domestic consumption and are responsible for storing, processing, and preparing food, handling livestock, gathering food, fodder and fuelwood, managing the domestic water supply, and providing most of the labor for post-harvest activities [21]. At the same time, they are challenged in each of what the IPCC identifies as the four pillars of food security: concerning availability, women have less opportunity to grow food; concerning access, gendered norms can leave women with smaller portions at mealtimes, less money to buy food, and fewer transport options to get to market; concerning utilization, women can have different nutritional needs, for example, during pregnancy and breast-feeding; and, concerning stability, they are disproportionately affected by food strikes and often reduce intake more than others when food is short [21]. Women in the global South accordingly have great responsibility for maintaining food security but little control over the factors that constitute and affect productivity and post-harvest activities.

The 'feminization of agriculture,' with many women working as small scale, subsistence farmers, has been attributed to family income diversification that draws men away from farming in Africa, the Caribbean, and Latin America, where, for example, in Chile and Panama, by 2013, three out of every ten farms were run by women [22]. This phenomenon can increase women's responsibility and contribution to decision-making, for example, thereby strengthening their empowerment. It can also provide an income either through employment or opportunity to sell small amounts in local markets to buy family necessities such as school fees and uniforms for children. Yet rural women have little opportunity to work in well-paying positions and face multiple challenges as farmers. The feminization of agriculture can leave women even more vulnerable to poverty and jeopardize their food security [22]. 
The 'feminization of agriculture' is in fact exacerbated by the 'feminization of poverty.' Approximately $9 \%$ of the world's estimated 570 million farms are in Africa; 41 million of these are small holdings of less than two hectares ( 5 acres) that are owned by families who produce $80 \%$ of Africa's food $[23,24]$ (p. xi). Despite economic growth of $4.5 \%$ in the 1990 s, Africa was the only region that failed to meet the Millennium Development Goal of cutting poverty in half by 2015 [25]. World Bank projections concentrate the world's poor increasingly in Africa, where between 1990 and 2012 poverty increased by 100 million people, from 284 to 388 million, despite the proportion of people living on less than $\$ 1.90$ a day falling from $56 \%$ to $43 \%$ during the same period [26]. In southern Africa, $43 \%$ of households are female-headed, though Africa as a whole has $26 \%$ female-headed households containing $20 \%$ of the population [26]. Disproportionately disadvantaged households are often headed by women who are widows, divorced or separated, or single [27]. Glazebrook [13] records women supporting as many as 17 people in their household, including their children and, for example, children of a deceased sister, a sister who has lost her sight, and other extended family members unable to support themselves. The feminization of poverty puts not just women but also their children and other family members at risk of hunger.

Ghana has made significant progress in reducing poverty, with agricultural production playing a key role. In 2008, agricultural contribution to Ghana's GDP constituted 32\% [28]. A mere decade later, Ghana had attained low-middle income status in World Bank classification [29], with agriculture accounting for 54\% of GDP and 40\% of export earnings [30]. Between 2011 and 2015, however, its GDP had actually dropped and its economic growth rate had fallen from $14 \%$ to $3.9 \%$, in part because of climate change that continues to be an economic threat [31]. The role of agriculture in addressing Ghana's poverty accordingly does not necessarily indicate increased agricultural productivity so much as stable productivity while other factors contributing to the GDP decline. As we show below, however, a climbing GDP and increase in exports can actually indicate an increase in the lived experience of poverty, especially when 'land grabs' displace women's subsistence agriculture with corporate, industrial farming.

Women in the global North are not impacted by poverty in the same way as women in the South, simply because of the difference in scale between the two economies. For example, in 2017, U.S. farms contributed over $\$ 132$ billion to the U.S. total GDP of over $\$ 19$ trillion [32,33], while Ghana's farms contributed $\$ 11.6$ billion to their total GDP of $\$ 59$ billion [34]. The global North is, however, beginning also to experience the 'feminization of agriculture,' especially at the level of farm management. As discussed above, the U.S., Canada, and Europe report a marked increase in the number of female farmers [3,9]. These numbers appear to indicate that the agricultural sector is moving towards gender parity, as more women control land and take leadership positions in farming operations. In North America, women make up approximately $47 \%-61 \%$ of the total workforce $[5,34]$. In Canada, women now make up approximately $28 \%$ of farmers [5]. The proportion of women farmers in the U.S. rose from $5.2 \%$ in 1978 [35] to $36 \%$ in 2017 [9]. This increase is impressive, as farms in the global North tend to be large scale economic operations that prioritize the production of market crops, in contrast to agriculture in the global South, which focuses on small-scale production aimed at providing subsistence for the farmers and their families.

Increased visibility of women in agriculture could, however, also be partially the result of changes in how survey data is collected. For example, the 2017 USDA survey previously allowed takers to identify only one primary producer (the decision-maker on the farm), but it was recently revised to allow survey takers to report multiple primary producers or decision-makers [36]. This change resulted in an increase in the number of women reported, which is not surprising as $96 \%$ of all farms in the U.S. are family operated [9,37]. Additionally, the survey's focus on primary producers may contribute to the global North's history of discounting women's contributions in agriculture. The survey focuses on who owns or manages the farm. Thus, by design, it excludes those who perform work but who are not property owners or managers. Historically, women were often excluded from decision-making roles [38], yet they made substantial contributions on the farm, as farming was and is a family affair [39]. 
Thus the 'feminization of agriculture' in the global North is a result of likely both increased recognition of women's contributions in agriculture and increasing numbers of women moving into agriculture in decision-making roles.

This increase in both recognition and participation can be contributed to wide-spread social and political changes in the global North [10], but it is also connected to efforts to address poverty and hunger. In Canada, approximately $9.1 \%$ of households are food insecure, with $5.2 \%$ of children not receiving adequate nutrition [40], while 5\% of Australian households are food insecure [41]. These numbers increase dramatically in the U.S., with $11.5 \%$ of adults and $17.5 \%$ of children living in food insecure households in 2016 [42]. In the global North, some populations are more vulnerable to food insecurity than others, with single-parents, the unemployed or underemployed, children, and members of minority groups experiencing higher rates of hunger than other populations [42,43]. While the number of people facing food insecurity is not as dire as in the global South, in both contexts, women and children, on average, experience food insecurity at higher rates than men [44,45]. Additionally, living in 'food deserts,' or areas where it is difficult to access fresh fruits and vegetables, is associated with higher rates of food insecurity [45]. Women farmers play an active role in agricultural projects aimed at providing community benefits, including affordable food for food insecure communities [46,47]. The numbers of community supported agriculture projects (CSAs), urban agriculture projects, and farms with direct-to-consumer sales have been on the rise in recent years. The percentage of women running these operations is higher than in other areas of agriculture, even though these operations are less profitable from an economic perspective [37]. This is not surprising as women farmers tend to prioritize community health and the public good over increasing crop yields [48,49]. Thus, the goal of addressing hunger is another contributor to the increase of women in agriculture in the global North. As in the global South, investing in women's farming is generally correlated with increasing food security of communities.

The UN Sustainable Development Goals (SDGs) [50] support such investment, are steeped in intent to empower women, and understand women's role in agriculture. SDG1 on poverty, SDG2 on hunger and food security, and SDG5 on equal rights all discuss women's right and need to have land access, and SDG2 also aims to double agricultural productivity and women's incomes through that access, as well as access to resources and inputs, knowledge, financial services, markets and value addition opportunities, and alternative employment. Women are, however, not explicitly connected to other SDGs directly relevant for productivity increase, for example, the technologies discussed in SDGs 9 and 17. In SDG6 on water, the sanitation and hygiene point indicates 'special attention' to the needs of women and girls, but irrigation is crucial for increasing crop yields and women need special attention on this also. This attention is especially important because institutionalized gender bias marginalizes women farmers with respect to irrigation and technologies in the global North but also in the South where humanitarian crises in hunger are already underway. The SDGs risks reproducing the shortfalls of the Millennium Development Goals if their vision does not extend to driving the systemic change that women need if they are, in the global South, to sustain adequate productivity to meet food security needs. For example, globally, development projects often include women in implementation while leadership and empowerment require women's participation in project design and planning as well as implementation. Many a well-meaning development project has failed because a detail only too familiar to women on-the-ground was overlooked by governance and policy makers. Women need to be at the table, but also to participate in setting the agenda.

In response to the recognition of women's crucial role in feeding others, investing in women's farming is generally thought to increase their productivity. If this is the case, such investment could reduce human suffering and support gender justice as a distributive issue with respect to economic inequities. It could also remediate intergenerational justice in that nutrition has lifelong impacts on childhood development. Ross [51] argues, however, that there is not enough evidence to support a correlation between investment in women's farming and productivity increase. The case of Ghana, where the majority ( $77 \%$ ) farm for subsistence [1] and women are responsible for $55 \%$ to $87 \%$ of 
productivity [52] (p. 75), [53] demonstrates the pressing necessity for a decisive answer as to whether and in what way investing in women's farming can increase productivity.

\section{Climate Impacts on Agricultural Productivity and Food Security}

The Intergovernmental Panel on Climate Change (IPCC) notes that differentiated impacts, vulnerability, risk perception, behaviors and coping strategies for climate change related to food security derive from gendered cultural norms [21]. While most climate-related studies of land and agriculture focus on food availability by assessing impacts on food production, studies are increasingly addressing impacts on food access, for example, prices; utilization, for example, nutritional quality; and stability, for example, risk, damage, and loss from increasing extreme weather and other events such as earthquakes and volcano-eruptions events, with low-income producers and consumers likely most affected with respect to all these factors because of lack of resources to invest in adaptation and diversification [21]. Low-income producers in both the global South and North are for the most part women who are together the most harmed concerning productivity, despite a marked difference in their economic situation that exposes women in the South to greater vulnerability with respect to access, utilization, and stability.

Globally, in breach of gender and distributive justice, women are at $10 \%$ higher risk of hunger than men [54]. Women in Africa are especially vulnerable to hunger, despite their agricultural work. Africa has been and is experiencing multiple and increasing humanitarian crises in hunger. Only about $4 \%$ of sub-Saharan Africa is irrigated [55], so climate is a major influence on agricultural productivity and Africa is extremely vulnerable to unpredictable and changing weather patterns. The region is increasingly experiencing heat, drought, flooding, and increased pests and disease that reduce productivity [56] (p. 21). Farmers in Africa already face extreme weather events of drought and flooding. For example, in Ghana, where less than $1 \%$ of land is irrigated and almost all farmers rely entirely on rainfall [57,58], the 2007 rainy season brought a long drought across the north of the country that reduced productivity substantially. The drought ended in a devastating flood left 56 people dead, more than 330,000 homeless, and many entirely without the meager crop they had been able to salvage during the drought that would have been their food supply until the next rainy season [13] (p. 763). For subsistence farmers, who grow to feed their family rather than for market, this was catastrophic.

Adaptations already being implemented still leave crop and food security at 'high' risk in 2030-2040 and 'very high' risk in 2080-2100, though 'high adaptation' efforts might keep production at 'medium' risk if Global Mean Surface Temperature (GMST) increase remains below $2{ }^{\circ} \mathrm{C}$. At $4{ }^{\circ} \mathrm{C}$, even with 'high adaptation,' risk is 'very high,' and the IPCC makes several recommendations [56] (p. 2):

- Technological adaptations, e.g., stress-tolerant crop varieties and irrigation;

- Alternative income generation and diversified livelihoods;

- Improved smallholder access to bank accounts and credit in order to access production resources and agricultural inputs;

- Support from government and other sources to implement early-warning systems for weather and other threats; and

- Agronomic adaptations in agroforestry and conservation agriculture.

The IPCC also recommends gender-oriented policy. The fact that women are widely known in both the global South and North to have limited access to agricultural technology and finance indicates a weakness in international understanding of women subsistence farmers' situations that cannot be addressed by policy interventions. As was identified in UN approaches working toward SDGs, IPCC solutions propose in-system fixes, while what is called for is systemic change. Unless strategies for increasing women farmers' productivity are connected with injustice remediation, i.e., unless women have access to the resources the IPCC recommends, they cannot succeed. Impediments to women's farming are ethical and justice issues as well as technical problems; solutions for the latter are limited by the former. 
The reality is that subsistence farmers are vulnerable to unpredictable weather when they depend entirely on rain to grow their crop [59] (p. 1218). Climate impacts that decrease land capacity to produce are already well documented [60-62]. The IPCC more than a decade ago predicted African declines by as much as $50 \%$ by 2020 , with 'high confidence' of declines in cereal and grain crops that are a mainstay of the African diet [63] (p. 50). Specifically, declines are expected up to $40 \%$, including $17 \%$ for wheat, $5 \%$ for maize, $15 \%$ for sorghum, and 10\% for millet [64]. Between 2006 and 2016, almost half the agricultural loss globally was crop ( $49 \%$ ) and livestock ( $36 \%)$. That is, $85 \%$ of agricultural loss was exactly what subsistence farmers in the global South primarily depend upon; and $83 \%$ of the damage was done by drought, to which Africa is especially susceptible [30] (p. 66).

Ross' argument that women's agricultural productivity cannot appropriately be measured can be addressed somewhat through consideration of food security. In a context where the national food-basket relies heavily on subsistence agriculture and women have been documented consistently and longitudinally, it is possible to identify a correlation between women's productivity and food security. Africa has for some time been suffering extensive food insecurity that had rapidly inflated into crises. In 1990, 12 African countries were in food crisis; by 2010 the number had doubled to 24 and 19 of them had experienced such crisis in eight years or more between 2005 and 2015 [11] (p. 27). By 2008, 21 of the world's 36 food-insecure countries (i.e., over 58\%), were in Africa [65]. Globally in 2017, one in nine people were hungry [66], though by 2015, every fourth African was undernourished [11] (p. 12); that is, Africa was home to $27 \%$ of the world's undernourished [11] (p. 10) and 220 million Africans, including many children, were not getting enough to eat [11] (p. 8). In 2017, of the approximately 821 million undernourished globally, over 256 million (more than 31\%) were in Africa [66] (p. 6). Africa's hunger load is a global breach of distributive justice.

Ghana's 2017 Climate Risk Profile expects total crop failure to occur now every five years [31]. The changing climate is leading to loss of productive lands because of ecosystem deterioration and post-harvest losses during storage [67]. The consequences are yield reductions that decrease food access and thin adaptation options [68]. Rain-fed crops are highly sensitive to drought and the Government of Ghana (GoG) connects food production decline to drought [57]. The GoG attributes 55-60\% of Ghana's agricultural production to women [52] (p. 75), though the Social Watch Coalition (SWC) estimates women's production of food crops as high as $87 \%$ [53]. Presumably, the SWC is discussing subsistence farming while the GoG intends corporate. The GoG data may not be an indication of women's situation with respect to agricultural productivity given the food security crisis. By 2012, in Ghana's Upper Eastern Region, for example, 38\% of households have been experiencing some level of food insecurity (6.4\% severe, $21.9 \%$ moderate, $10.1 \%$ mild) for some time, and over $10 \%$ of households in the Upper East, Upper West, and Northern Regions combined were experiencing severe food insecurity and over $44 \%$ moderate [69].

As Glazebrook [70] shows, women in Ghana's Upper Eastern Region are adapting to the changing rains through crop selection. Instead of growing millet and groundnut that are unreliable without consistent rainfall, they are switching to rice. Unfortunately, this is not a long-term solution as rice crop decline is $10 \%$ for each $1{ }^{\circ} \mathrm{C}$ rise in GMST [71]. More immediately pressing, however, is that rice does not provide the protein of traditional crops such as millet or groundnut, or the millet's calcium. Protein is crucial for brain and muscle development, but also lack of protein causes various diseases, including Kwashiorkor characterized by edema (swelling), an enlarged liver with fatty infiltrates, and frequent infections. Millet is also high in calcium needed for bone development in children and for pregnant or lactating women and their fetus or baby. Women are sacrificing their nutritional base just to have something to feed the family as they desperately accept lifelong impacts on their children's physical and cognitive development and every family member's health, including their own, simply in order to stave off starvation.

These women are receiving little if any federal or international support. In the village of Zuarungu, for example, outside Bolgatanga in Ghana's north, the only help the women have received is a rice-grinding machine donated by Oxfam that in polishing the rice, removes most of whatever nutrition 
the rice actually offers. The international community seems oblivious to the nutritional costs of the women's loss of food sovereignty, and the breaches of agricultural and food justice, as well as intergenerational justice, that women and their families are subjected to in consequence of a changing climate that is driving productivity decline in traditional crops. Moreover, African fossil fuel emissions are per capita among the lowest in the world, accounting for as little as $3.7 \%$ of total global emissions [72]. Distributive justice is doubly breached insofar as the region least driving climate change is most suffering its consequences. Furthermore, gender justice is contravened by women's over-representation among the most extremely poor who have the least capacity to generate greenhouse gases and the least resources to respond to food insecurity [12] (p. 80) [65] though they continue to show their resilience in their ongoing adaptation efforts.

In the global North, weather impacts are the most significant indicators of a changing climate, so agriculture is impacted. The IPCC [21] reports that in Australia, rainfall decline and rising temperatures caused water-limited yield potential to decline by $27 \%$ from 1990 to 2015, even with positive impacts of elevated atmospheric CO2. High-temperatures during the crop reproduction stage were found in particular to have negative effects on wheat yields, especially when amplified by low rainfall. In Europe, impacts have varied across the region but since 1989 continent-wide wheat yields have reduced by $2.5 \%$ and barley by $3.8 \%$, while maize and sugar beet yields have increased slightly. Italy is experiencing the worst yield declines, i.e., $5 \%$ or more, because of amplification by a drying trend. Country-specific research shows positive and negative impacts, but data is not systematic across the region. In presenting this information on climate impacts in the global North, the IPCC takes the standard policy approach to gender. They promise gender-relevance throughout, and provide a section dedicated to gender. 'Gender' appears in this section 15 times, and 14 elsewhere in the chapter's remaining 80 pages of narrative. The relegation of gender to its own section rather than consistent integration fails to recognize the ubiquity of gender differentials throughout climate impacts and furthers women's invisibility in agriculture that undermines both understanding how women, who are among the most vulnerable to climate change, are impacted and policy development to support women's adaptations.

Farmers in the global North are best placed to mitigate the climate contributions of farming, for example, using anaerobic digesters to convert animal waste into fertilizer and biogas. Subsistence farmers in the global South typically cannot access such resources, and bottom-up, Community-Based Adaptation (CBA) [73] is likely their best option. Unfortunately, however, CBA can retain or even amplify the gender bias that affects women farmers in communities in both the global South and North. The UN Framework Convention on Climate Change (UNFCCC) was established in 1992 but only took its Gender Decision some 20 years later [74]. Recognition justice of women as agents of change in climate mitigation and adaptation was only possible because a woman leader, Christiana Figueres, was Executive-Secretary and worked with Mary Robinson, former President of Ireland, to have the Decision put to vote. The Decision called for gender parity in high-level delegations as well as gender as a standing issue on the annual Conference of Parties meeting agenda, but focus was largely on mitigation and discussion of adaptation, considered a women's issue, was long delayed, likely with consequences to women's agricultural productivity, until the Climate Adaptation Fund was established in 2001 and launched in 2007 [70].

\section{Biases and Barriers}

UN Women [75] on rural women and girls reports that globally, women's work is subject to significant gender bias in both the South and North. Laws restrict 2.7 billion women from having the same job choices as men and in some countries, men can prevent their wife from working outside the home. Women are over-represented in informal employment, for example, as contributing family members, and this work is largely unrecognized despite the essential support it provides to economies. When women are paid, the gender wage gap is $23 \%$ globally. Women spend on average 2.5 times more time than men on unpaid care and domestic labor, though as shown below, in Africa, differential gender 
workloads begin at a young age, increase over time, and continue in adult life. In some 40 economies worldwide, women's entrepreneurship is half or less that of men. Only 5\% of Fortune 500 Chief Executive Officers are women. National economies are accordingly not gender-inclusive or principled with respect to gender justice in either the global North or South.

UN Women [76] on economic empowerment further reports that women are only $12.6 \%$ of global landowners, despite almost a third of women's employment globally being in the agricultural sector. The proportion of women working in agriculture decreases in wealthier economies, i.e., only $2.6 \%$ of agricultural workers are women in high-income countries and $9.5 \%$ are women in upper-middle-income countries. Agriculture is, however, the most important employment sector for women in low-income and lower-middle-income countries. We conclude that women's agriculture is inversely proportional to a country's wealth, and that this differential likely means that as the proportion of women farmers in a country is larger, the likelihood of increased poverty and decreased access to resources is also larger.

Indeed, in the global South, a 'gender gap' remains in agriculture as women face persistent inequalities that affect their access to resources and undermine food security [13,77]. A 2017 survey of 104 countries found women to be less than $13 \%$ of agricultural landowners-despite, as noted above, that 1.4 billion of the 2.5 billon (i.e., over $50 \%$ ) people relying on subsistence agriculture for their livelihood are women-and further found that women are more susceptible to livelihood insecurity, less able to access resources, with less collective voice and agency and less of a role in both household and community decision-making than men $[13,78]$. Women in Africa, Asia, and Latin America in fact typically have access to smaller land areas, fewer livestock, and less technology, water, banking, credit and markets, in comparison with men [13,22,78]. Largely responsible for family food security, women are nonetheless consistently under-resourced and hampered by gender bias and socio-political marginalization.

Ghanaian women, for example, still face widely recognized inequalities identified decades ago, though Ghana's gender parity index in education reached 0.77 in 2018 [79], i.e., for every 100 male students, there were 77 females. In 2017, only $54 \%$ of women had a bank account, compared to $62 \%$ of men [80]. In agriculture, women face long-standing, persistent challenges of limited access to credit, machinery, labor, fertilizer, and agricultural extension services [81] (Sussex 1994), weak land tenure rights [82,83], and exclusion from particular farming practices, for example, agroforestry [52]. In rural areas, men take part five times more in wage-employment than women and $72 \%$ of self-employed women in agriculture are within the low-income classification, compared to $48 \%$ of men [1] (p. 7). Men hold 3.2 times more farms than women, including 8.1 times more medium- and large-sized farms, i.e., five acres or more [1] (p. 7). Contrary to Sustainable Development Goal 5 (SDG5) on gender equality and empowerment [50], women are more likely to be engaged in unpaid domestic work than men: $65 \%$ of men spend from 0 to $10 \mathrm{~h}$ per week on domestic activities, while $89 \%$ of women spend 10 or more hours; similarly for girls aged $7-11,80 \%$ of boys do household chores 10 or less hours per week, while more than half of girls do at least 10 — some as many as 50 —hours of domestic work each week, with even greater gender disparity among children aged 12-14 [1] (p. 8). Females carry a substantially larger labor burden than men, and women are also heavily economically disadvantaged. At the same time, factors like climate change, pollution, and other environmental degradation of land, forests, and water have disproportionate impacts on women who mostly bear the brunt of coping [76]. In short, women farmers work harder, with less resources, for less compensation.

In the global North, there are several biases and barriers that impact women entering into the agricultural sector, as well as recognition of their contributions. Land access has a long history of being used to maintain systems of power in both Canada [84] and the United States [85], including racial segregation [86], patriarchal oppression [49], and the consolidation of resources into the hands of those in power. Throughout the U.S., there is a legacy of using zoning ordinances to maintain an unequal racial hierarchy, through the removal of 'undesirables' from neighborhoods and barring land access [85]. Discriminatory practices have been a part of land policies since the introduction of zoning in the early 1900s, as planners and government officials initially developed these tools to effectively 
control land and enact 'social reforms' [86]. Australia also experienced a similar pattern of using land access to reinforce social exclusion and discrimination [87]. In the global North, these practices, historical biases, and dominant discourses are often effectively combined to form a complex network of barriers for women, though it should be noted that systems of oppression vary from context to context.

For women farmers, various institutionalized practices and social norms continue to impact female producers negatively. Farming is an inordinately male-dominated profession in the global North, due to social norms, historical patriarchal laws, and land transfer practices $[37,39,88]$. It is not surprising, then, that there is a legacy of women's contributions not being equally valued. As mentioned above, Australia has a history of not recognizing women's work on the farm [89], though most farms are operated by families and families typically include women. Over $98 \%$ of farms in Canada and $97 \%$ of farms in the U.S. are family operated [5,9], as farming in the global North is seen as a family enterprise [39]. Family member contributions historically were not, however, recognized equally, as men were conceptualized as 'farmers' and women were dismissed as 'farmwives' in the dominant discourse [37,90]. According to Fremstad and Paul [37] (p. 6), 'despite the fact that the family farm depended on women's work for survival, women continued to work as invisible farmers.' These gender norms and biases resulted in women's work being largely ignored in national farm policies, and women's exclusion from agricultural knowledge exchange, for example, agriculture extension, and from roles of authority on the farm [38]. This male-dominated context pushed the USDA to identify women as socially disadvantaged farmers and to allow for the use of targeted loan funds to offset barriers [91].

Despite women steadily gaining recognition for their work, gender biases constrain their land management options $[48,92,93]$ and negatively impact income earned [37]. These biases are reflected in formal and informal practices that effectively marginalize women in agriculture. In particular, Carter [48] argues that women's management options are constrained in several important ways. Women have been excluded from spaces where agricultural knowledge is produced and exchanged $[38,94]$ and this has resulted in a myopic focus on men's experiences and needs, even in areas where women are dominant such as organic and sustainable agriculture $[95,96]$. Increasing prioritization of large-scale agriculture over other approaches favored by female producers $[37,48]$ changes farming environments and needs, which in turn reduces the number of management options available for women and the effectiveness of these options. Women report, moreover, that male farmers and agency staffers commonly push them to adopt management strategies that do not align with their values or goals [48]. This type of coercion has been linked to perceived illegitimacy of women as decision-makers in agricultural contexts $[10,48]$. It has also been attributed to the prioritization of men's farming needs as they aim to increase crop yields, while women tend to prioritize community health and the public good over increased productivity [49].

Gender discrimination also plays a factor in that lenders, suppliers, and other farmers are susceptible to gender biases. In this vein, Fremstad and Paul [37] argue that 'farming is one of the most unequal professions in the U.S. today,' as women earn approximately $40 \%$ less farm income than men. They highlight other factors that likely influence the gender pay gap in agriculture. For example, women tend to operate smaller farms, both in terms of sales and acreage under cultivation. They more readily engage in sustainable agriculture practices, including using organic methods, running Community Supported Agriculture operations, and selling direct-to-consumer. While these practices are important for supporting community health [15,97], they are associated with lower overall profits, which may be both a consequence and a cause for prioritization, in lending practices and policy settings, of men's experiences and needs [37]. For example, the USDA has a history of being accused of denying loans to women at a higher rate than male farmers [91]. Gender bias in agriculture in the global North is systemic and institutionalized discrimination.

The invisibility of women's labor is both a symptom and driver of bias against women farmers and their marginalization globally, despite Marilyn Waring's ground-breaking work over thirty years ago arguing that, because subsistence crops do not have the market presence that register productivity in traditional economic reckonings, women farmers' contributions are often unseen-their labor 
literally cannot be counted [98]. As subsistence farmers or workers on smallholder, profit-earning farms owned by male family members, women are not paid [99]. Likewise, women farmers in the global North are marginalized and overlooked despite their significant contribution. Ross [51] argues in fact that 'women's productivity' is 'a difficult concept to define, let alone to measure,' because women's contributions cannot be disentangled when both men and women operate a farm together. The default position in data collection is to reckon productivity based on markets and landownership, both of which are gender-biased metrics largely non-inclusive of women in both the global South and North. Women farmers face biases that deny their right to equal treatment, contravene distributive justice, and compromise their food sovereignty, while systemic bias in economic analyses denies them recognition justice through blindness to their presence, labor, and productivity.

\section{Land and Corporate Consolidation}

There are robust legal and social barriers restricting women's access to farmland [37] that have economically disadvantaged women, harmed their ability to leave farming for another career, and reduced the status of rural women in comparison to women living in urban areas [10]. Over 400 million women produce the majority of the world's food supply, yet women account for only $12.8 \%$ of agricultural landholders globally [75] and own less that $20 \%$ of the world's land [76,100]. In 90 countries, in fact, women do not share men's rights to own land [76]. Women's agricultural productivity is threatened in the global South and North because of similar, though different in the details, challenges in land acquisition and retention. Without access to land, women cannot begin to be agriculturally productive, yet ownership and inheritance traditions and practices impede women's secure access to land, while displacement by corporate and industrial farming remains a threat to land retention for women who do not control the land they work.

Lack of land tenure is a significant problem for women subsistence farmers in Africa who work to feed their family. In Ghana, for example, when a women's husband, i.e., the landowner, passes away, her brothers-in-law typically come to claim the land she has farmed for decades and still depends on. Women can take their case to the official, i.e., post-colonial, legal system, but typically they appeal to their local chief under the traditional justice system. It is not uncommon for the chief to decide that the woman has the right to farm the land until her natural death [70]. This creates uncertainty, however, as it means that the woman's fate depends on the vagaries of individual choice and how much the chief can be relied upon. It also leaves a daughter, typically the third, who according to traditional practice is kept in the family to assist the mother, in a difficult situation when the mother passes away in that the daughter no longer has access to the land, so can grow no food for herself and dependents, and has little life-choice options available. Her life has in effect been forfeit to unpaid labor ending in dependency on the goodwill of others. Her life is not her own; but in fact, her mother's was not her own either, though she did have more autonomy than the daughter.

A woman can also lose access to her farm if the land is sold by the owner, whether that is her husband, another family member, or the person she is renting it from. Development project personnel can import gender bias from their home context, and historically there have been cases in which land was bought from a husband, who may or may not have understood what he was agreeing to, with no consideration, either deliberately or based on bias, that the wife should be consulted because of the consequences to family food security of losing access to the land. Outside the growing season, even well-intentioned developers might simply overlook women's land use because of the invisibility of their labor [70].

Corporate take-over of land can be justified by the fact that increases in cash crop production, especially at large scale, grow a country's GDP and GNP in what appears to be economic improvement, though in actual fact the lived experience of poverty increases for a woman and her family when she loses access to the land [13]. If the corporation fails, she can still be denied access to the land that now sits empty and unused, in limbo after the corporation went bankrupt or simply withdrew from a failed venture. Women have little ability to seek remedy through the courts in the official legal 
system that is expensive and hard to navigate for village women who have limited education and literacy, and may not speak the language of the court. Women's livelihoods are lost as they wait for an outcome while the planting and growing seasons pass by. Land-grabbing also happens through bribery and corruption, resulting in compromise of community trust that compounds gender injustices of land displacement, loss of livelihood, food insecurity, environmental degradation through poor soil practices and chemical inputs, and poverty exacerbation [70]. Large-scale land acquisitions that displace locals have, moreover, been identified as causes of declines in agricultural production [101].

The land tenure barrier has also been a challenge for women farmers in the global North where they relatively recently gained the right to own property. In the U.S., women were granted this right in 1850, and in Canada, in 1884 [102]. Women still, however, face serious barriers to owning and managing land $[10,88]$. Land management is particularly problematic for women in agriculture because they still work in the shadow of lack of land ownership that historically restricted women's power on farmsteads [103]. Access to land determines whether a woman can move into the agricultural profession, but also whether she can take a leadership role on the farm.

Gender disparities in farmland ownership are at least partially caused by gendered views concerning who is considered to be a 'farmer' and the implications of this perception for agricultural land inheritance practices. Cultural narratives concerning agriculture in the global North privilege specific types of practitioners who fit gendered ideals of productivity and thus marginalize others who may want to move into the profession [48]. These narratives work to maintain agriculture as a 'masculine' sphere and act as a barrier to women's participation and gender parity in farming $[90,94,104]$. For example, even though great strides have been made in recognizing women's rights and achieving gender parity in key professions, 'it is farmers' sons, not farmers' daughters, who become farmers and take over ownership and management of the family farm ... [D]aughters, even today, are neither considered to be farmers nor likely to inherit family farmland [10] (p. 347). Similar to women's experience in the global South, where in Ghana, for example, land is traditionally assumed to pass on to brothers rather than wives, in the North, agricultural land typically goes to sons. In fact, an Australian comparative study of international patterns of rural inheritance in Canada, the U.S., Japan, and several countries in Europe, found little variance across the global North: sons are more likely to inherit, while 'most daughters are excluded from inheritance of land' [105] (p. ix). Daughters typically move into agriculture by marrying a farmer, or they leave the profession [10]. While the number of female farmers is increasing, exclusionary practices associated with farmland inheritance, and the cultural narrative that supports the 'masculinization of farming' in the global North, in contrast with the 'feminization of farming' in the global South, are formidable barriers to obtaining gender parity in the agricultural sector.

These exclusionary practices also have long-term economic impacts for female farmers. The historically accepted ways that women enter farming leaves them particularly vulnerable as it reduces their authority and power on the farm [103], undermines their ability to become a primary producer, and places them in a position where leaving the farm could have negative economic consequences. For example, because a woman often enters farming through marriage, divorce can mean walking away from the land into which she has invested her labor and moving on without capital, a job, or a credit history [10]. When women do inherit land, they often do so later in life [106]. They inherit from husbands, rather than fathers, so divorce can also preclude this return on their labor investment. Inheritance practices not only function as barriers to women's entry into the agricultural profession, they also reduce women's ability to leave. While farming is becoming more inclusive, it is important to note that traditional practices and cultural narratives can still have life-long impacts on women's agency and economic stability and thriving.

Similar to the global South, the global North has experienced a sharp rise in the corporate consolidation of agriculture and this trend has repercussions for women moving into agriculture. This trend is occurring at every level of food systems and supply chains, as multinational corporations work to consolidate agricultural holdings and production capacity [107]. Even in Europe, where small 
farms are conceptualized as the 'cornerstone' of agriculture, there is 'a tendency towards consolidation', as the number of large farms grows [108]. North America is experiencing accelerated consolidation at an unprecedented rate. By $2015,51 \%$ of U.S. farm production came from producers who make at least $\$ 1$ million dollars in yearly sales and $36 \%$ of all crops were produced on farms consisting of at least 2000 acres [109]. Although not as severe, Canada also reported a reduction of farm numbers and increase in farm size [5]. There is a tendency towards greater specialization, as livestock ventures move away from farming crops and field crop operations grow 2-3 types of crops, on average, rather than adopting multi-crop approaches [109]. While the majority of crops are still produced by family farms, corporations exercise greater power over management decisions through the use of farm contracts that can mandate everything from farming equipment to animal feed. There has been considerable consolidation at the farm level as smaller producers are pushed out of the industry by buy-outs though they may still work what used to be their land [110].

These trends in agriculture in the global North exacerbate land access issues that act as barriers for women to enter farming. As farms consolidate, there are fewer opportunities to obtain farmland (as there are fewer farms) and this land is typically more expensive or a larger initial investment is required to enter into the field. If a large percentage of production is coming from farms that make at least $\$ 1$ million dollars a year, it is difficult to compete, simply due to economies of scale. While these factors act as barriers for all new farmers regardless of gender, they provide bigger hurdles for female producers because women are an already disadvantaged group. In this context, female farmers are more likely to rent land, rather than own it [49], and this translates into a reduction of economic profits and constrains land management options, discussed above [91].

In addition, these trends constrain the type of agriculture that women can practice. Sustainable agricultural initiatives are typically small-scale operations that do not suffer from the additional land access barriers. Women are up to three times more likely to go into sustainable agriculture [111], even though these farms are not as economically viable [38]. This trend is largely attributed to sustainable agriculture ideals and communities being more compatible with women's farm identities and values [111]. Land access also plays a role, however, in nudging producers to move into more accessible farming ventures. In the United States, agricultural consolidation, combined with an increasing public interest in farming, has resulted in a landscape where conventional farms are growing larger, even as small producers proliferate. Sustainable agriculture offers an alternative community more supportive of women operators that challenges both the cultural narratives that support gendered inheritance patterns and the male-oriented model of agricultural development.

\section{Results}

Results include findings that women farmers in the global South share commonalities with respect to bias and discrimination. Section 3 provides data and evidence on women's situations as farmers with respect to the feminizations of poverty and agriculture, vulnerability of female-headed households, increases in recognition of women's farming, gender limitations of the Millenium Development and Sustainable Development Goals, and economic disparity between the global South and North. This material shows that commonalities across the South/North divide include systemic and institutionalized gender bias and discrimination. Women face systemic bias and discrimination in economic marginalization, diminished roles in decision-making, and limited, if any, access to capital, resources, and technologies. Women have more possibility for land ownership than in the past in the North, but globally, some 90 countries still deny women land tenure. Historical barriers to women's land ownership are still in place and work to exclude women from land as well as the resources they need to increase and optimize their productivity.

Section 4 provides data and evidence that climate impacts exacerbate challenges in women's farming in the global South collected from organizations such as the UN and UN-related international organizations, for example, the IPCC, the Food and Agriculture Organization, the International Fund for Agricultural Development, and the World Food Programme, and from global non-governmental 
organizations such as the International Food Policy Research Institute, and a number of academic researchers. Evidence in this literature shows that women, especially in poor areas, are much more challenged with respect to mobility or pursuit of an alternative livelihood. Lack of resources and language challenges make relocation difficult. In north-east Ghana, the majority of women farmers in rural areas far from the capital speak multiple local languages, but neither of Ghana's national languages. Likelihood of exacerbated vulnerability, risk, and exploitation also deters relocation except in extreme situations such as violent conflict that necessitates flight for immediate survival, though climate-related ecosystem breakdown is now recognized as a driver in the nexus dynamics of refugee flight [112]. In the meantime, lack of formal training and a skill set for office or sales work, for example, limits women to local employment options that often have poor labor conditions and weak pay rates, and risk of exposure to gender harassment and other abuses.

Having established that climate change makes things especially worse for women farmers in the global South, subsequent sections provide evidence on particular challenges women in the South and North experience in common. Section 5 drills down to provide further evidence of gender bias in access to technology and finance as well as discrimination, lack of recognition of their contribution, and limited power and voice. Section 6 likewise provides further evidence of women's challenges in the global South and North concerning land acquisition and retention with further evidence concerning the challenges of corporate land appropriation.

There are also significant differences between the global South and North. Women farmers in the North are better equipped for resilience in the face of a changing climate or other causes of crop loss. Insurance and economic resources can counter loss and damage from catastrophic weather events. Relocation can be an option, as can a change of livelihood, despite the challenges of making such changes. Social welfare supports, for example, unemployment payment and food stamps, are typically available in some form throughout the global North to meet individual and family needs during transitions. A woman's risk as a farmer in the global North is primarily economic, but not therefore unharming. Bankruptcy is tragic and carries substantial emotional and life-situation consequences. For a woman in the global South, however, crop failure means hunger crisis with a range of impacts from nutritional deficiency to starvation. The global South is largely bereft of social safety nets.

\section{Discussion}

Our analysis has identified both issues experienced by women globally in common and marked differences between South and North. Women virtually everywhere share inclusion and access challenges. They can also have a similar practice for very different reasons, for example, while women in the North often choose to farm organically, women in the South practice 'organic' farming largely by default in that poverty renders out of reach anything that must be purchased. A strong difference is that in the South, women's agriculture is largely a subsistence livelihood, while in the North, it is a business.

Part of the challenge of responding to humanitarian crises in hunger is that scale in agriculture is inversely proportional to sustainability because large scale relies on mass monoculture production that depends on synthetic fertilizers, insecticides, herbicides and other extension inputs that include proven carcinogens; for example, Monsanto's use of glyphosate in its herbicide, Roundup, has recently been connected to liver cancer. The goal of increased productivity that drives profits has displaced the aim inherent in agriculture to produce food. Women's agricultural activities, whether chosen in the global North or necessitated by circumstance in the South, works in much greater contact with the soil and the crop. This does not generate an idealized experience of the 'happy peasant' but provides a closer relationship and understanding of plant and livestock as living entities deeply connected to human experience. We thus suggest that women's agricultural practices already favor more sustainable food and agricultural practices in the long term than industrial farming. The goal need not be profit alone, but a reliable livelihood that values sustainable practices. 
We conclude that the challenges that women farmers face in the global South and North increase their vulnerability to climate and weather conditions, undermine their resilience, and impede their capacity. They must overcome gender bias and cross barriers that block access to virtually every aspect of their work-land, finance, resources, workload, and leadership. Removing these barriers is key to obtaining gender equity in agriculture, whether in the U.S. [10] or elsewhere across the planet. Accordingly, we conclude that women's productivity is reduced by these challenges and can be enhanced by their removal.

Ross [51] (p. 48) argues that, although 'most studies suggest that women would be about as productive as men as farmers, given access to similar resources,' the evidence is neither sufficient nor clear that targeting women would increase their productivity, and there are, moreover, studies 'that suggest the opposite.' We have shown, however, that women farmers' situations are affected by a large number of factors that interact complexly in systems determined by politics and governance, finance, social and cultural context, all of which remain embedded in global patriarchy and, of course, weather. Women are simply too clearly hampered by gender-based limitations not to conclude that these impediments are reducing their productivity and that it therefore could be increased by removal of these impediments.

That is, showing that there is inadequate evidence to conclude that gender-equity in farming would increase women's productivity is morally reprehensible, when this may be used to justify not investing in women's farming in the global South where women very much need support to address factors like climate change that reduce their productivity and threaten food system collapse. It is of course fallacious to believe that lack of evidence of $x$ implies not- $x$, but banks want certainty. The quantitative assessment that concludes 'inadequate evidence' should not trump the qualitative argument we have made that removal of multiple, severe impediments will increase women farmers' productivity because such removal gives women access to resources that are widely known to increase yield. If someone's legs have been tied together, insufficient evidence to conclude that untying them will enable them to run does not justify leaving the person tied up. Likewise, with respect to women's farming in the global South, long-standing exploitations by the global North and current practices in the global North have reduced and continue to harm the capacity of the global South to meet its food requirements. Restorative justice requires that capacity be increased and current harming practices stop. These things are achieved by addressing the many justice breaches and compromises of autonomy and sovereignty that impede women's agriculture through systemic change.

Ross has the wrong end of the stick, as it were. Seeking proof that women farmers' productivity would match men's when all factors except gender are equal is a breach of gender justice. Gender justice requires starting from the position that gender difference, ceteris paribus, does not make women less productive farmers. Gender bias asks women to prove they are equally capable; gender justice asks for proof they are not when principles of distributive justice are upheld. We have provided much evidence that simply being a woman reduces productivity not because of inherent ability but because being a woman triggers the 'perfect storm' of gender-based exclusions, biases, and harms, that range from extreme workload to the burden of poverty and fall disproportionately to women. Gender bias in agriculture is globally entangled in a mass of distributive justice issues, as well as food sovereignty and autonomy compromise and intergenerational justice.

Women's orientations, approaches to, and experiences of farming are different based on location, training, and socio-political factors. Location brings economic factors. Global hunger is very much associated with poverty and is therefore focused in the global South that experiences severe distributive injustice with respect to wealth and therefore also food security. Increasing action to raise women's agricultural productivity in the global South has the potential to remedy humanitarian crises in hunger and egregious breaches of justice for women and children. Land tenure, irrigation, and access to drought-resistant crop strains would very much improve their productivity capacity. 


\section{Conclusions}

We have concluded that investing in women's agriculture can increase productivity. In the global South, especially Africa, productivity increase is unlikely to be sustainable without global transition from fossil fuels to renewables consistent with IPCC recommendation to keep GMST increase no higher than $2{ }^{\circ} \mathrm{C}$. Even without climate change, agriculture is steeped in biases and limitations on women's farming that hold back productivity. Climate change affects all growers and is increasingly threatening the economic stability of farmers in the global North through droughts, heat waves, fires, and floods, all of which put crops at risk. Climate mitigation debates at UNFCCC annual Conferences of Parties make it abundantly clear, however, that the issue is not at its fundament fossil fuels so much as a global, neoliberal, economic system that the North would prefer to retain [113] in order that a relatively small group of special interests need not relinquish the ongoing benefits of fossil fuel exploitation, despite climate impacts exacerbating hunger in the global South. The breaches of distributive, gender, and agricultural justice, the compromise of food sovereignty, and the double distributive breach of climate justice in terms of greenhouse gas contributions made and impacts suffered, can only be solved together because what is needed is not a tweak of policy but systemic change. Concerning climate change, what is needed is not just a transition, but a just transition.

'Investing' in women's agriculture must, then, be rethought. Though we cannot provide a complete framework for investing in women's agriculture, we provide here recommendations for structural changes toward such a framework. Support should provide access to capital and technologies, but in both the global South and North, 'investment' that does not include systemic interventions in agricultural policy, governance, and education systems cannot succeed. Men and women in the global South and North working in agricultural policy, finance, and education would benefit from gender training, and agricultural students in higher education could increase their disciplinary and trade stewardship through a course in agricultural ethics on gender, food sovereignty and other issues, as well as education in indigenous and traditional ecological knowledge and agricultural practices. Women in the South can also benefit from agricultural education and training as women do in the North. These strategies have the potential to increase women's access, capacity, and productivity because they break down systemic, institutional gender bias and raise men's awareness to the injustices and limitations of such bias, but also the benefits of more ethically balanced agricultural practices that can overcome attitudes largely grounded in fear and loss of power or control. In short, women grow most of what goes into national food-baskets in the global South despite increasingly difficult conditions that exploit their labor and violate their rights.

Women in the global South and indigenous people who farm throughout the planet, have already been taught by elders who pass down knowledge acquired over generations of practice that is expert and locally relevant, so integration into local education systems, including institutions of higher education, of traditional knowledge would provide knowledge-transfer pathways for women's long-standing understanding of best on-the-ground practices. These women are resilient and continue to find ways to provide food security through rain-harvesting, seed banks and seed sharing, for example. The National Biodiversity Board Committee in India declared the Zaheerabad region an agro-biodiversity heritage site, in fact, for its diverse collection of seeds, some of which were on the verge of being eliminated by large-scale, monoculture, industrial farming [114]. Such projects succeed because women support each other by sharing the organization's workload, but also because women take leadership opportunities that increase visibility and participation for themselves and other women. The Deccan Development Society that requested Zaheerabad to be declared a heritage site began as an agricultural cooperative of Dalit ('untouchable') women that rented and remediated land the owners considered worthless. The women dug rills in the soil to retain rainfall and removed rocks. Their productivity was so profitable that landowners, higher caste men who would normally not speak to them, would come to their courtyard and to drink tea and ask if they did not want to rent more land [115]. With very little support, these women living in extreme poverty, with marginal literacy and 
little education, not only created an organization with a revolving fund of over $\$ 80,000$ USD, but also radically improved their social status.

Investment also needs to provide unique gender supports, for example, gender budgets, vulnerability and impact assessments throughout government-funded research and projects, and gender quotas for agriculture-related government departments and industry associations. Gender quotas ensure inclusion. For example, increased numbers of women in agricultural research can make research more gender-sensitive and inclusive, and in contexts such as Latin America, where women tend to follow advice of other women, it is important to employ women as extension agents [116]. Gender budgets bring more financial assistance to women that can provide access to more options and more equitable distribution of farming resources. Several countries in the global North are already providing financial assistance. The USDA, for example, has farm loan programs for socially disadvantaged farmers, including women. This practice needs bolstering, however, to reach more women, more realistically as adequate funding is crucial for improving land access and economic support is a key component of improving women's representation and agricultural productivity. Budgets and assessments provide metrics for project assessment that is crucial for determining what successfully increases women's productivity, what actually works against it, and what is neutral but wastes time and resources, but also for maintaining the transparency and accountability that keeps projects on track. Such metrics could also provide the data Ross has shown is terribly needed.

Improving land access is imperative for increasing gender justice and women's productivity in agriculture. In the North, addressing gender disparities in land inheritance and farm transmission would provide women with more opportunity to farm. As the majority of farms are family enterprises, uneven access to land at the family level exacerbates the lack of female representation in the agricultural sector and reduces female control of resources and management opportunities. In addition, when coupled with the consolidation of farms, this trend funnels women into agricultural specialties, such as community supported agriculture [111], that typically offers fewer assets and is less productive or economically viable. Programs are needed to incentivize women to be principal producers. Likewise, in the global South, granting women land tenure would provide land acquisition and retention security to enable ongoing productivity by protecting women from land appropriation by extended family and 'land grabs' by corporations.

Sustainable agriculture in the global North better supported by government and research institutions would improve women farmers' situation in which they are three times more likely to go into sustainable agriculture than men [111] but receive relatively little support. Rather, farming policies and research tend to reflect needs and values associated with large-scale agricultural production. This institutionalized discrimination creates an unequal farming environment. For example, producers engaged in sustainable agriculture often cannot use the research and technologies developed for use on large scale farms, that moreover, governmental subsidies play an important in supporting. More support for farming types favored by women would give them better farm management options and technologies that better fit their needs. This could presumably increase the economic viability of women's farms, as it apparently already does for farmers that access existing technologies, that in turn might incentivize more women to enter the farming sector.

It must be noted that in contexts where women choose to farm, as in the global North where it is a business and career rather than a family necessity as in the global South, women who farm tend toward sustainable practices such as organic farming that is less disruptive of the local ecosystem and carries less human health impacts than industrial agriculture. In the global South, women's farming is organic by default when women simply do not have the resources to buy extension products to increase yield. Their work is also, however, a care activity to meet daily requirements of the material necessities for family and community. Women's farming and indigenous agriculture tend to promote traditional practices of food and seed sovereignty, access for all, and sustainable growing and consumption in the long-term based on qualitative factors of system and human well-being, in stark contrast with industrial farming that values economic goals reckoned primarily using quantitative 
in quarterly and annual reports. The logic and values at work in women's organic farming and industrial approaches are markedly different in orientation toward 'productivity as profit' versus productivity as system maintenance toward sustainable food sources and consumption. This is not a difference between men and women but systems that determine farming differently because of value and goal differences. Sustainable agriculture is guided by more than economic efficiency. Community connectedness, ecologism, self-reliance, justice, stewardship, and family health also inform this agricultural paradigm [117]. Rather than attempting to support women's farming in the South or North using the assumption that they aim to develop into large-scale, industrial farming for export, listening to women's articulations of how they understand their farming with respect to local markets, their place on the land, and their needs, including technologies, to reach their goals would likely be more successful for improving food security for women in the South and stabilizing women's livelihood. Women farmers are after all autonomous and resilient and should be trusted to understand their situation and environment better than anyone else.

Gender parity and women's full participation in farming in the global North will likely have an impact on farming as a whole, as gender inclusion has in many other contexts. For instance, agricultural policy and research focus shift from privileging large farms to supporting smaller farms, favored by women who dominate sustainable agriculture, would be a valuable contribution to food-production sustainability. In other words, increased productivity can come in two ways: industrial-size farms, or large numbers of smaller farms. The impact of gendered values and intent in farming toward systemic change in how food needs are satisfied may hold the promise not just of increased productivity but long-term sustainability of farming and income that values and aims at food production itself rather than merely profit. What is needed in both the global South and North to increase sustainable agricultural productivity is large-scale support for many, many women and men who are gender- and justice-oriented farmers.

Finally, we have come to three conclusions that pressingly need further discussion. First, women farmers in the global South and North, perhaps surprisingly, are subjected to quite similar gender biases. Secondly, women's food security in the global South is in humanitarian crisis largely exacerbated by climate change though some leaders in the global North refuse to mitigate emissions. Third, women farmers tend towards goals and values that are more likely to be sustainable than contemporary approaches in industrial agriculture. Each of these points warrants further attention and change to improve women's lives, the lives of those around them, and the lives of future generations.

Author Contributions: Conceptualization, T.G. and S.N.; methodology, T.G., S.N. and E.O.; formal analysis, T.G. and S.N.; investigation, T.G., S.N. and E.O.; data curation, T.G., S.N and E.O.; writing-original draft preparation, T.G., S.N. and E.O.; writing-review and editing, T.G. and S.N.; project administration T.G. All authors have read and agreed to the published version of the manuscript.

Funding: This research received no external funding.

Conflicts of Interest: The authors declare no conflict of interest.

\section{Appendix A}

Table A1. Justice issues, rights, and sovereignty.

\begin{tabular}{lc}
\hline \multicolumn{1}{c}{ Justices and Harms } & Section/Paragraph \\
\hline agricultural justice & $2 / 4,9 / 1,9 / 7$ \\
autonomy and sovereignty & $8 / 5,8 / 6$ \\
climate justice & $9 / 7$ \\
distributive justice & $1 / 4,2 / 4$ \\
hunger & $4 / 6,4 / 9$ \\
climate change, double breach & $4 / 9,9 / 7$ \\
gender & $3 / 9,4 / 2,5 / 9,8 / 6,8 / 6,8 / 7,9 / 7$ \\
future generations & $2 / 4,8 / 6,8 / 7$ \\
\hline
\end{tabular}


Table A1. Cont.

\begin{tabular}{lc}
\hline \multicolumn{1}{c}{ Justices and Harms } & Section/Paragraph \\
\hline intergenerational justice & $2 / 4,3 / 9,4 / 9,8 / 6,8 / 7$ \\
food justice & $2 / 4,4 / 9$ \\
food security and sovereignty & $1 / 7,5 / 9$ \\
gender justice & $4 / 9$ \\
gender and distributive justice & $3 / 9,4 / 2,5 / 9,8 / 6,8 / 6,8 / 7,9 / 7$ \\
gender and justice-oriented farmers & $9 / 8$ \\
land & $5 / 9,9 / 6$ \\
men's awareness & $9 / 2$ \\
land grab injustices & $6 / 4$ \\
recognition justice & $4 / 11,5 / 9$ \\
restorative justice & $8 / 5$ \\
rights, women's & $6 / 6,9 / 2$ \\
land tenure & $5 / 4,6 / 1$ \\
SDG5 & $3 / 8$ \\
tradition justice systems (Africa) & $6 / 2$ \\
\hline
\end{tabular}

\section{References}

1. FAO. Gender Inequalities in Rural Employment in Ghana: An Overview; Gender, Equity and Rural Employment Division of FAO: Rome, Italy, 2012; Available online: http://www.fao.org/docrep/016/ap090e/ap090e00.pdf (accessed on 31 May 2020).

2. FAO. Gender: The Female Face of Farming. Available online: http://www.fao.org/gender/resources/infogra phics/the-female-face-of-farming/en/ (accessed on 31 May 2020).

3. European Commission. Females in the Field: More Women Managing Farms across Europe. Available online: https://ec.europa.eu/info/news/queens-frontage-women-farming-2019-mar-08_en (accessed on 31 May 2020).

4. Eurostat. Data Explorer. Available online: http://appsso.eurostat.ec.europa.eu (accessed on 31 May 2020).

5. Statistics Canada. "Gender, Diversity and Inclusion Statistics.". Available online: https://www.statcan.gc.ca/ eng/topics-start/gender_diversity_and_inclusion (accessed on 31 May 2020).

6. Alston, M.; Clark, J.; Whittenbury, K. Contemporary feminist analysis of Australian farm women in the context of climate changes. Soc. Sci. 2018, 7, 16. [CrossRef]

7. Pratley, J.E. Agriculture-from macho to gender balance. In Proceedings of the 18th Australian Society of Agronomy Conference, Ballarat, Victoria, Australia, 24-28 September 2017; p. 4.

8. Hoppe, R.; Korb, P. Characteristics of Women Farm Operators and their Farms. Economic Information Bulletin No. (EIB-111); United States Department of Agriculture: Washington, DC, USA, 2013.

9. USDA. 2017 Census of Agriculture Data Now Available. Available online: https://www.usda.gov/media/pre ss-releases/2019/04/11/2017-census-agriculture-data-now-available (accessed on 31 May 2020).

10. Alsgaard, H. Rural inheritance: Gender disparities in farm transmission. North Dakota Law Rev. 2012, 88, 347-408.

11. FAO; IFAD; WFP. The State of Food Insecurity in the World 2015: Meeting the 2015 International Hunger Targets: Taking Stock of Uneven Progress; Food and Agriculture Organization of the United Nations: Rome, Italy, 2015.

12. FAO; ECA. Regional Overview of Food Security and Nutrition; Food and Agriculture Organization of the United Nations and United Nations Economic Commission for Africa: Accra, Ghana, 2018; Available online: http://www.fao.org/3/CA2710EN/ca2710en.pdf (accessed on 31 May 2020).

13. Glazebrook, T. Women and climate change: A case Study from Northeast Ghana. Hypatia 2011, 26, 762-782. [CrossRef]

14. Glazebrook, T.; Opoku, E. Defending the defenders: Environmental protectors, climate change and human rights. Ethics Environ. (Spec. Issue Honor Vic. Davion ed. Piers Stephens) 2018, 23, 83-110. [CrossRef]

15. Noll, S.; Werkheiser, I. Local food movements: Differing conceptions of food, people, and change. In Oxford Handbook of Food Ethics; Barnhill, A., Doggett, T., Budolfson, M., Eds.; Oxford University Press: Oxford, UK, 2018; pp. 112-139. 
16. Hall, G.; Gandolfo, A. Poverty and Exclusion Among Indigenous Peoples: The Global Evidence. World Bank Blogs. Available online: https://blogs.worldbank.org/voices/poverty-and-exclusion-among-indigenous-pe oples-global-evidence (accessed on 31 May 2020).

17. Glazebrook, T.; Gessas, J. Standing Rock: Water protectors in a time of failed policy. In The Wonder of Water: Lived Experience, Policy and Practice; Stefanovic, I., Ed.; University of Toronto Press: Toronto, ON, Canada, 2020; pp. 171-196.

18. McIntyre, J.K.; Davis, J.; Macneale, K.; Anulacion, B.; Hinman, C.; Scholz, N.; Stark, J. Soil bioretention protects juvenile salmon and their prey from the toxic impacts of urban stormwater runoff. Chemosphere 2015, 123, 213-219. [CrossRef]

19. FAOSTAT. Available online: https://www.fao.org/faostat/en/\#home (accessed on 31 May 2020).

20. Nyasimi, M.; Huyer, S. Closing the gender gap in agriculture under climate change. Agric. Dev. 2017, 30, 37-40.

21. Mbow, C.; Rosenzweig, C.; Barioni, L.G.; Benton, T.G.; Herrero, M.; Krishnapillai, M.; Liwenga, E.; Pradhan, P.; Rivera-Ferre, M.G.; Sapkota, T.; et al. Food security. In Climate Change and Land: An IPCC Special Report on Climate Change, Desertification, Land Degradation, Sustainable Land Management, Food Security, and Greenhouse Gas Fluxes in Terrestrial Ecosystems; Shukla, P.R., Skea, J., Buendia, E.C., Masson-Delmotte, V., Pörtner, H.-O., Roberts, D.C., Zhai, P., Slade, R., Connors, S., van Diemen, R., et al., Eds.; United Nations' Intergovernmental Panel on Climate Change: New York, NY, USA, 2019.

22. Vaqué, J. Agronoticius, Agricultural News form Latin America and the Caribbean. Rural Women-A Key Asset for Growth in Latin America and the Caribbean. Available online: http://www.fao.org/in-action/agro noticias/detail/en/c/501669/ (accessed on 31 May 2020).

23. Lowder, S.K.; Skoet, J.; Raney, T. The number, size, and distribution of farms, smallholder farms, and family farms worldwide. World Dev. 2016, 87, 16-29. [CrossRef]

24. FAO. The State of Food and Agriculture: Leveraging Food Systems for Inclusive Rural Transformation; Food and Agriculture Organization of the United Nations: Rome, Italy, 2017.

25. United Nations. The Millennium Development Goals Report 2015; United Nations: New York, NY, USA, 2015.

26. Beegle, K.; Christiaensen, L.; Dabalen, D.; Gaddis, I. Poverty in a Rising Africa: Africa Poverty Report-Overview; International Bank for Reconstruction and Development/World Bank: Washington, DC, USA, 2016.

27. Milazzo, A.; van de Walle, D. Women Left Behind: Poverty and Headship in Africa; World Bank: Washington, DC, USA, 2015.

28. Diao, X. Economic Importance of Agriculture for Sustainable Development and Poverty Reduction: Findings from a Case Study of Ghana; Global Forum on Agriculture, Policies for Agricultural Development, Poverty Reduction and Food Security, OECD: Paris, France, 2010; Available online: https://pdfs.semanticscholar.org/cc29/8897ea ef9e2be618edd2fc6d42a19249b87c.pdf (accessed on 31 May 2020).

29. World Bank. Data for Lower Middle Income, Ghana. Available online: https://data.worldbank.org/?location s=XN-GH (accessed on 31 May 2020).

30. FAO in Ghana. Available online: http://www.fao.org/ghana/fao-in-ghana/ghana-at-a-glance/en/ (accessed on 31 May 2020).

31. USAID Fact Sheet. Climate Risk Profile: Ghana. Available online: https://www.climatelinks.org/resources?s earch_api_views_fulltext=Climate+change+risk+profile+Ghana+ (accessed on 31 May 2020).

32. USDA. What is Agriculture's Share of the Overall U.S. Economy? Available online: https://www.ers.usda.g ov/data-products/chart-gallery/gallery/chart-detail/?chartId=58270 (accessed on 31 May 2020).

33. World Bank 2020 World Development Indicators. Available online: http://datatopics.worldbank.org/world-d evelopment-indicators/ (accessed on 31 May 2020).

34. United States Department of Labor. 12 Stats about Working Women|U.S. Department of Labor Blog. Available online: https://blog.dol.gov/2017/03/01/12-stats-about-working-women (accessed on 31 May 2020).

35. Kalbacher, J.Z. A Profile of Female Farmers in America. Rural Development Research Report; United States Department of Agriculture: Washington, DC, USA, 1985.

36. USDA. Census of Agriculture. Available online: https://www.nass.usda.gov/AgCensus/FAQ/2017/index.php (accessed on 31 May 2020).

37. Fremstad, A.; Paul, M. Opening the farm gate to women? The gender gap in U.S. agriculture. J. Econ. Issues 2020, 54, 124-141. [CrossRef] 
38. Leckie, G. 'They never trusted me to drive': Farm girls and the gender relations of agricultural information transfer. Gend. Place Cult. 1996, 3, 309-326. [CrossRef]

39. Ramey, E. Class, Gender and the American Family Farm in the 20th Century; Routledge: London, UK, 2014.

40. McIntyre, L.; Galesloot, S. Hunger in Canada. Can. Med. Assoc. J. 2008, 178, 730. [CrossRef]

41. McKay, F.H.; Haine, B.C.; Dunn, M. Measuring and understanding food insecurity in Australia: A systematic review. Int. J. Environ. Res. Public. Health 2019, 16, 476. [CrossRef] [PubMed]

42. Coleman-Jensen, A.; Rabbitt, M.; Gregory, C.; Singh, A. Household Food Security in the United States in 2016; Economic Research Report ERR-237; United States Department of Agriculture: Washington, DC, USA, 2017.

43. Flores, H.; Amiri, A. Addressing food insecurity in vulnerable populations. Am. J. Nurs. 2019, 119, 38-45. [CrossRef]

44. WhyHunger.org. Just the Facts about Hunger in the US \& The World. Available online: https://whyhunger. org/just-the-facts/ (accessed on 31 May 2020).

45. AAFP Home: American Academy of Family Physicians. Available online: https://www.aafp.org/dam/AAFP/ documents/patient_care/everyone_project/food-insecurity-brief.pdf (accessed on 31 May 2020).

46. Mcmahon, M. Resisting globalization: Women organic farmers and local food systems. Can. Women's Stud. 2002, 21, 203-206.

47. Sumner, J.; Llewelyn, S. Organic solutions? Gender and organic farming in the age of industrial agriculture. Capital. Nat. Social. 2011, 22, 100-118. [CrossRef]

48. Carter, A. 'We don't equal even just one man': Gender and social control in conservation adoption. Soc. Natur. Resour. 2019, 32, 893-910. [CrossRef]

49. Chiappe, M.B.; Flora, C. Gendered Elements of the Alternative Agriculture Paradigm. Rural Soc. 1998, 63, 372-393. [CrossRef]

50. United Nations Sustainable Development Goals. Transforming our World: The 2030 Agenda for Sustainable Development. United Nations A/Res/70/1. Available online: https:/sustainabledevelopment.un.org/content/ documents/21252030\%20Agenda\%20for\%20Sustainable\%20Development\%20web.pdf (accessed on 31 May 2020).

51. Ross, C.R. Women and agricultural productivity: Reframing the issues. Dev. Policy Rev. 2018, 36, 35-50. [CrossRef]

52. IMF. Republic of Ghana, Ghana Poverty Reduction Strategy: 2003-05; International Monetary Fund: IMF Country Report No. 03/56, March 6 2003; IMF Publication Services: Washington, DC, USA, 2003; Available online: https://www.imf.org/en/Publications/CR/Issues/2016/12/30/Ghana-Poverty-Reduction-Strategy-Pa per-16390 (accessed on 31 May 2020).

53. Social Watch Coalition. National Reports-Ghana: MDGs Remain Elusive. Available online: http: //www.socialwatch.org/node/12082 (accessed on 31 May 2020).

54. United Nations. Women's Progress on the Sustainable Development Goals: The Gender Snapshot 2019. UN Women/DESA. Available online: https:/www.unwomen.org/en/digital-library/publications/2019/09/progre ss-on-the-sustainable-development-goals-the-gender-snapshot-2019 (accessed on 31 May 2020).

55. Irrigating Africa: IFPRI Study Examines the Dimensions of Africa's Irrigation Problem. Available online: https://www.ifpri.org/blog/irrigating-africa (accessed on 31 May 2020).

56. IPCC WGIIA SP. Part A: Global and sectoral aspects, summary for policymakers. In AR5 Climate Change 2014: Impacts, Adaptation, and Vulnerability. Contribution of Working Group II to the Fifth Assessment Report (AR5) of the Intergovernmental Panel on Climate Change; Field, C.B., Barros, V.R., Dokken, D.J., Mach, K.J., Mastrandrea, M.D., Bilir, T.E., Chatterjee, M., Ebi, K.L., Estrada, Y.O., Genova, R.C., et al., Eds.; Cambridge University Press: Cambridge, MA, USA; New York, NY, USA, 2014; pp. 1-32. Available online: https: //www.ipcc.ch/report/ar5/syr/ (accessed on 31 May 2020).

57. MOFA. A Report on Agricultural Statistics. Available online: http://mofa.gov.gh/site/?page_id=79 (accessed on 31 May 2020).

58. World Bank. The Costs to Developing Countries of Adapting to Climate Change: New Methods and Estimates. Available online: http://siteresources.worldbank.org/EXTCC/Resources/EACC-june2010.pdf (accessed on 31 May 2020). 
59. IPCC WGIIB. Part B: Regional Aspects. Africa. In Climate Change 2014: Impacts, Adaptation, and Vulnerability. Contribution of Working Group II to the Fifth Assessment Report of the Intergovernmental Panel on Climate Change; Barros, V.R., Field, C.B., Dokken, D.J., Mastrandrea, M.D., Mach, K.J., Bilir, T.E., Chatterjee, M., Ebi, K.L., Estrada, Y.O., Genova, R.C., et al., Eds.; Cambridge University Press: Cambridge, MA, USA; New York, NY, USA, 2014; pp. 1199-1266. Available online: https://www.ipcc.ch/report/ar5/wg2/ (accessed on 31 May 2020).

60. Christiano, T. Introduction to symposium on climate change. Pol. Phil. Econ. 2014, 13, 317-319. [CrossRef]

61. Gentle, P.; Thwaites, R.; Race, D.; Alexander, K. Differential impacts of climate change on communities in the middle hills region of Nepal. Nat. Hazards 2014, 74, 815-836. [CrossRef]

62. Elsner, J.B.; Kossin, J.P.; Jagger, T.H. The increasing intensity of the strongest tropical cyclones. Nature 2008, 455, 92-95. [CrossRef]

63. IPCC SYN. Climate Change 2007: Synthesis Report. In Contribution of Working Groups I, II and III to the Fourth Assessment Report (AR4) of the Intergovernmental Panel on Climate Change; Pachauri, R.K., Reisinger, A., Eds.; IPCC: Geneva, Switzerland, 2007; p. 104. Available online: https://www.ipcc.ch/report/ar4/syr/ (accessed on 31 May 2020).

64. Knox, J.; Hess, T.; Daccache, A.; Wheeler, T. Climate change impacts on crop productivity in Africa and South Asia. Environ. Res. Lett. 2012, 7, 1-8. [CrossRef]

65. FAO; IFAD; UNICEF; WFP; WHO. The State of Food Security and Nutrition in the World 2018; FAO: Rome, Italy, 2018.

66. de Pinto, A.; Demirag, U.; Haruna, A.; International Food Policy Research Institute. Climate Change, Agriculture, and Food Crop Production in Ghana. Policy Note Number 3. Available online: http: //ebrary.ifpri.org/utils/getfile/collection/p15738coll2/id/127134/filename/127345.pdf (accessed on 31 May 2020).

67. Vermeulen, S.J.; Aggarwal, P.K.; Ainslie, A.; Angelone, C.; Campbell, B.M.; Challinor, A.J.; Hansen, J.W. Agriculture, Food Security and Climate Change: Outlook for Knowledge, Tools and Action. CCAFS Report No. 3. Copenhagen: CGIAR-ESSP Program on Climate Change, Agriculture and Food Security. Available online: https://ccafs.cgiar.org/publications/agriculture-food-security-and-climate-change-outlook-knowle dge-tools-and-action\#.Wsw6gS7wa70 (accessed on 31 May 2020).

68. World Food Programme. Comprehensive Food Security \& Vulnerability Analysis: Ghana 2012. Focus on Northern Ghana. Available online: https://documents.wfp.org/stellent/groups/public/documents/ena/wfp25 7009.pdf (accessed on 31 May 2020).

69. Glazebrook, T. Climate adaptation in the global South: Funding women's farming. In Reinvigorating Eco-Feminism: New Themes and Directions; Phillips, M., Rumens, N., Eds.; Routledge: London, UK, 2015; pp. 111-131.

70. Peng, S.; Huang, J.; Sheehy, J.E.; Laza, R.C.; Visperas, R.M.; Zhong, X.; Centeno, G.S.; Khush, G.S.; Cassman, K.G. Rice yields decline with higher night temperature from global warming. Proc. Natl. Acad. Sci. USA 2004, 101, 9971-9975. [CrossRef]

71. Canadell, J.G.; Raupach, M.R.; Houghton, R.A. Anthropogenic $\mathrm{CO}_{2}$ emissions in Africa. Biogeosciences 2009, 6, 463-468. [CrossRef]

72. Kabasa, J.D.; Sage, I. Climate change and food security in Africa. In Climate Change in Africa: Adaptation, Mitigation and Governance Challenges (CIGI Special Report); Besada, H., Sewankambo, N.K., Eds.; Centre for International Governance Innovation (CIGI): Waterloo, ON, Canada, 2009; pp. 21-25. Available online: https://www.cigionline.org/sites/default/files/climate_change_in_africa_3.pdf (accessed on 31 May 2020).

73. Reid, H. Ecosystem- and community-based adaptation: Learning from community-based natural resource management. Clim. Dev. 2016, 8, 4-9. [CrossRef]

74. Decision 23/CP.18 (2012) 'Addendum: Part Two: Action taken by the Conference of the Parties at its eighteenth session.'. Report of the Conference of the Parties on its eighteenth Session, Doha, Qatar, 26 November-8 December 2012; UNFCCC: Bonn, Germany. Available online: https://unfccc.int/documents/7645 (accessed on 31 May 2020).

75. United Nations, Women (2018). Learn the Facts: Rural Women and Girls. 2018. Available online: https://www.unwomen.org/en/digital-library/multimedia/2018/2/infographic-rural-women (accessed on 31 May 2020).

76. United Nations. Women Facts and Figures: Economic Empowerment. Available online: https:/www.unwo men.org/en/what-we-do/economic-empowerment/facts-and-figures (accessed on 31 May 2020). 
77. Johnson-Welch, C.; Alemu, B.; Msaki, T.P.; Sengendo, M.; Kigutha, H.; Wolff, A. Improving Household Food Security: Institutions, Gender, and Integrated Approaches. 2000. Available online: http://www.hubrural.org /IMG/pdf/basissem9911_panel3c.pdf (accessed on 31 May 2020).

78. Balakrishnan, R.; Fairbairn-Dunlop, P. FAO Regional Office for Asia and the Pacific: Prospects and Paradoxes; FAO, Regional Office for Asia and the Pacific: Bangkok, Thailand, 2005.

79. World Bank. School Enrollment, Tertiary (Gross), Gender Parity Index (GPI)-Ghana. Available online: https://data.worldbank.org/indicator/SE.ENR.TERT.FM.ZS?locations=GH\&most_recent_value_de $\mathrm{sc}=$ false (accessed on 31 May 2020).

80. World Bank. Ghana Economic Update: Enhancing Financial Inclusion. Available online: https://www.worl dbank.org/en/country/ghana/publication/ghana-economic-update-enhancing-financial-inclusion (accessed on 31 May 2020).

81. Sussex, University of. Institute of Development Studies, Background Paper on Gender Issues in Ghana; BRIDGE, Overseas Development Assistance: Falmer, UK, 1994.

82. Awanyo, L. Land tenure and agricultural development in Ghana: The intersection of class, culture and gender. In Critical Perspectives on Politics and Socio-Economic Development in Ghana; Puplampu, K., Tettey, W., Berman, B., Eds.; Brill Academic Publishers: Boston, MA, USA, 2003; pp. 273-304.

83. Whitehead, A.; Tsikata, D. Policy discourses on women's land rights in sub-Saharan Africa: The implications of the re-turn to the customary. J. Agrar. Chang. 2003, 3, 67-112. [CrossRef]

84. Roher, J. Zoning out discrimination: Working towards housing equality in Ontario. J. Law Soc. Policy 2016, 25, 2526-2553.

85. Rabin, Y. Expulsive zoning: The inequitable legacy of Euclid. In Zoning and the American Dream; Haar, C., Kayden, J., Eds.; Routledge Press: New York, NY, USA, 1989; p. 105.

86. Silver, C. The racial origins of zoning in American cities. In Urban Planning and the African American Community: In the Shadows; Thomas, J.M., Ritzdorf, M., Eds.; Sage Publications: Thousand Oaks, CA, USA, 1997; pp. 189-205.

87. Jayasuriya, D. Understanding Australian racism. Aust. Univ. Rev. 2002, 45, 40-44.

88. Whatmore, S. Farming Women: Gender, Work, and Family Enterprise; Macmillan: London, UK, 1991.

89. Alston, M. Breaking Through the Grass Ceiling: Women, Power E Leadership in Rural Australia; Harwood Academic: Amsterdam, The Netherlands, 2000.

90. Shortall, S. Power analysis and farm wives. Sociologia Ruralis 1992, 32, 431-451. [CrossRef]

91. United States Department of Agriculture. Hispanic and Women Farmers and Ranchers Claim Resolution Process; 50601-0002-21; United States Department of Agriculture: Washington, DC, USA, 2016.

92. Drunschke, C.G.; Secchi, S. The impact of gender on agricultural conservation knowledge and attitudes in an Iowa watershed. J. Soil Water Conserv. 2014, 69, 95-106. [CrossRef]

93. Twyman, J.; Muriel, J.; Garcia, M.A. Identifying women farmers: Informal gender norms as institutional barriers to recognizing women's contributions to agriculture. J. Gend. Agric. Food Secur. 2015, 1, 1-17. [CrossRef]

94. Sachs, C. The Invisible Farmers: Women in Agricultural Production; Rowman \& Allanheld: Totowa, NJ, USA, 1983.

95. Peter, G.; Bell, M.; Jarnagin, S.; Bauer, D. Coming back across the fence: Masculinity and the transition to sustainable agriculture. Rural Soc. 2000, 65, 215-233. [CrossRef]

96. Carolan, M. Barriers to the adoption of sustainable agriculture on rented land: An examination of contesting social fields. Rural Soc. 2009, 70, 387-415. [CrossRef]

97. DeLind, L.B. Are local food and the local food movement taking us where we want to go? Or are we hitching our wagons to the wrong stars? Agric. Hum Values 2011, 28, 273-283. [CrossRef]

98. Waring, M. If Women Counted: A New Feminist Economics; Harper \& Row: New York, NY, USA, 1988.

99. Jara, M. Latin American Rural Women call for Recognition and Policies. Inter Press Services: Food and Agriculture. Available online: http://www.ipsnews.net/2018/10/latin-american-rural-women-call-recognitio n-policies/ (accessed on 31 May 2020).

100. Villa, M. Women Own Less than $20 \%$ of the World's Land. It's Time to Give them Equal Property Rights. World Economic Forum. Available online: https:/www.weforum.org/agenda/2017/01/women-own-less-th an-20-of-the-worlds-land-its-time-to-give-them-equal-property-rights/ (accessed on 31 May 2020). 
101. Cotula, L.; Vermeulen, S.; Leonard, R.; Keeley, J. Land grabbing or development opportunity. In Agricultural Investment and International Land Deals in Africa; IIED/FAO/IFAD: London, UK, 2009.

102. Jensen, J. Promise to the Land: Essays on Rural Women; University of New Mexico Press: Albuquerque, NM, USA, 1991.

103. Braunstein, E.; Folbre, N. To honor and obey: Efficiency, inequality, and patriarchal property rights. Fem. Econ. 2001, 7, 25-44. [CrossRef]

104. Brandth, B. Changing femininity: The social construction of women farmers in Norway. Sociologia Ruralis 1994, 34, 127-149. [CrossRef]

105. Barclay, E.; Reeve, I.; Foskey, R. Australian farmers' attitudes toward succession and inheritance. In Keeping It in the Family: International Perspectives on Succession and Retirement on Family Farms; Lobley, M., Baker, J., Whitehead, J., Eds.; Routledge: London, UK, 2012; pp. 21-35.

106. Pilgeram, R.; Amos, B. Beyond 'inherit it or marry it': Exploring how women engaged in sustainable agriculture across farmland. Rural Soc. 2015, 80, 16-38. [CrossRef]

107. Sparling, D.; Quadri, T.; van Duren, E. Consolidation in the Canadian Agri-food Sector and the Impact on Farm Incomes; Canadian Agricultural Policy Institute: Ottawa, ON, Canada, 2005.

108. Eurostat. Small and Large Farms in the EU-Statistics from the Farm Structure Survey-Statistics Explained. Available online: https://ec.europa.eu/eurostat/statistics-explained/index.php?title=Small_and_large_farms _in_the_EU_-_statistics_from_the_farm_structure_survey\&oldid=406560 (accessed on 31 May 2020).

109. MacDonald, J.; Hoppe, R.; Newton, D. Three Decades of Consolidation in U.S. Agriculture; Economic Research Report 189; United States Department of Agriculture: Washington, DC, USA, 2018.

110. Wender, M. Goodbye family farms and hello agribusiness: The story of how agricultural policy is destroying the family farm and the environment. Villanova Envion. Law J. 2011, 22, 141-167.

111. Trauger, A. 'Because they can do the work': Women farmers in sustainable agriculture in Pennsylvania, USA. Gend. Place Cult. 2007, 11, 289-307. [CrossRef]

112. Glazebrook, T. Gender, climate, and conflict in forced migration. In Beyond Free Market: Social Inclusion and Globalization; Bakir, F., Ed.; Routledge: Abingdon, UK, 2020; Unpublished work.

113. Doelle, M. The legacy of the climate talks in Copenhagen: Hopenhagen or Brokenhagen? Carbon Clim. Law Rev. 2010, 4, 86-100.

114. Kumbamu, A. The agri-food sector's response to the triple crisis: Sustaining local social initiatives in Andhra Pradesh, India. Development 2012, 55, 104-111. [CrossRef]

115. Rao, V.R. 2019. Women farmers of India's Deccan Plateau. In Environmental Ethics, 3rd ed.; Schmidtz, D.D., Shahar, D.C., Eds.; Oxford University Press: New York, NY, USA, 2019; pp. 337-343.

116. IICA: The Role of Women in Latin America. Inter-American Institute for Cooperation on Agriculture. Available online: https://www.iica.int/en/press/news/innovation-agriculture-role-women-latin-america (accessed on 31 May 2020).

117. Piso, Z.; Werkheiser, I.; Noll, S.; Leshko, C. Sustainability of what? Recognising the diverse values that sustainable agriculture works to sustain. Environ. Values 2016, 25, 195-214. [CrossRef]

(C) 2020 by the authors. Licensee MDPI, Basel, Switzerland. This article is an open access article distributed under the terms and conditions of the Creative Commons Attribution (CC BY) license (http://creativecommons.org/licenses/by/4.0/). 